\section{INFLUENCE OF THE RELATIVE AGE EFFECT ON HEIGHT, MOTOR PERFORMANCE AND TECHNICAL ELEMENTS OF OLYMPIC VOLLEYBALL ATHLETES}

\author{
OEFEITO DA IDADE RELATIVA NA ESTATURA, DESEMPENHO MOTORE ELEMENTOS TÉCNICOS DOS \\ ATLETAS OLIMMICOS DE VOLEIBOL \\ EL EFECTO DE LA EDAD RELATIVA EN LA ESTATURA, DESEMPEÑO MOTOR Y ELEMENTOS TÉCNICOS DE LOS \\ ATLETAS OLIMMPICOS DE VÓLEIBOL
}

\begin{abstract}
Luiz José Frota Solon Junior ${ }^{1}$ (iD) (Physical Education Professional) Luiz Vieira da Silva Neto2,3 (D) (Physical Education Professional)

1. Universidade Federal do Ceará (UFC), Sobral, CE, Brazil.

2. Universidade Estadual Vale do Acaraú (UEVA), Sobral, CE, Brazil. 3. Universidade Federal do Ceará (UFC), Biotechnology Graduate Studies Program, Sobral, CE, Brazil.
\end{abstract}

\section{Correspondence:}

Luiz José Frota Solon Junior. Universidade Federal do Ceará (UFC - Campus of the School of Medicine), Biotechnology Graduate Studies Program (PPGB). Av. Comandante Maurocelio, Rua Tarciano da Rocha Pontes, 100, Sobral, CE, Brazil. 62.042-280. biotecnologiasobral@gmail.com

\begin{abstract}
Introduction: The Relative Age Effect (RAE) refers to the chronological age difference that occurs between athletes of the same age category, which can benefit individuals born in the first two quartiles of the year. This phenomenon is commonly studied in team sports, yet the results are still inconsistent, especially in volleyball. Objective:This study analyzed the distribution of the number of births per quartile of Olympic volleyball athletes and whether this would influence anthropometric/motor variables and technical elements. Methods: The sample consisted of 116 male athletes who scored during the Rio 2016 Olympics. For data analysis, we identified each athlete's quartile as well as data on height, attack and defensive (or block) range, and respective scores during the games. The Chi-square test was then used to verify interquartile distribution. To assess the normality of the other variables, we conducted the Kolmogorov-Smirnov test. Once accepted, one-way ANOVA was performed with the Bonferroni post-hoc test to verify significance between quartiles. A significance level of $p \leq 0.05$ was adopted. Results: There was no significant difference in the distribution of athletes between quartiles $(p=0.74)$. When comparing the other variables in terms of the athletes' trimester of birth, we did not observe any significant difference between height ( $p=0.79)$, attack $(p=0.59)$ and defensive range $(p=0.07)$, and in the scores for serving, attacking and blocking between quartiles either. Conclusion: The Relative Age Effect was not observed in Olympic volleyball athletes, therefore this phenomenon is not related to the athletes' performance. This shows that other possible variables may influence the development of these athletes, discarding the relative age phenomenon. Level of Evidence III; Retrospective and Comparative Study.
\end{abstract}

Keywords: Age distribution; Skills; Volleyball.

\section{RESUMO}

Introdução: O efeito da idade relativa (EIR) refere-se à diferença da idade cronológica que ocorre entre os atletas de uma mesma categoria de idade que pode beneficiar os indivíduos nascidos nos dois primeiros quartis do ano. Esse fenômeno é comumente estudado em esportes coletivos, entretanto, os resultados ainda são inconsistentes, principalmente, no voleibol. Objetivo: O presente estudo analisou a distribuição do número de nascimentos por quartil dos atletas olímpicos de voleibol e se isso influenciaria em variáveis antropométricas, motoras e em elementos técnicos. Métodos: A amostra foi composta por 116 atletas masculinos que pontuaram durante as olimpíadas do Rio 2016. Para análise de dados, foi identificado o quartil de cada atleta, assim como os dados referentes à estatura, alcance no ataque e bloqueio e as respectivas pontuações durante os jogos. Em seguida, utilizou-se o teste de qui-quadrado para verificar a distribuição entre os quartis. Para avaliar a normalidade das outras variáveis, foi efetivado o teste de Kolmogorov-Smirnov. Após aceito, foi realizado ANOVA - one way, com o post-hoc de Bonferroni, a fim de verificar as significâncias entre os quartis. Adotou-se o nível de significância de $p \leq 0,05$. Resultados: Não houve diferença significativa na distribuição dos atletas entre os quartis $(p=0,74)$. Quando comparamos as outras variáveis em relação ao trimestre de nascimento dos atletas, também não observamos diferença significativa entre a estatura $(p=0,79)$, alcance de ataque $(p=0,59)$ e bloqueio $(p=0,07)$, e nas pontuações de saque, ataque ebloqueio entre os quartis. Conclusão: 0 efeito da idade relativa não foi observado nos atletas olímpicos de voleibol, portanto, esse fenômeno não está relacionado ao desempenho dos atletas. Isso mostra que outras possíveis variáveis podem influenciar a formação desses atletas, descartando o fenômeno da idade relativa. Nível de evidência III; Estudo retrospectivo e comparativo.

Descritores: Distribuição por idade; Habilidades; Voleibol.

\section{RESUMEN}

Introducción: El efecto de la edad relativa (EER) se refiere a la diferencia de la edad cronológica que ocurre entre los atletas de una misma categoría de edad que puede beneficiar a los individuos nacidos en los primeros dos cuartiles del año. Este fenómeno se estudia comúnmente en deportes colectivos, entretanto, los resultados aún son inconsistentes, especialmente en el vóleibol. Objetivo: El presente estudio analizó la distribución del número de 
nacimientos por cuartil de los atletas olímpicos de vóleibol y sieso influenciaría en variables antropométricas, motoras y en elementos técnicos. Métodos: La muestra fue compuesta por 116 atletas masculinos que puntuaron durante las Olimpíadas de Río 2016. Para análisis de datos, fue identificado el cuartil de cada atleta, así como datos referentes a la altura, alcance en el ataque y bloqueo, y sus respectivas puntuaciones durante los juegos. Luego, se utilizó el test de Chi-cuadrado para verificar la distribución entre los cuartiles. Para evaluar la normalidad de las otras variables, se realizó el test de Kolmogorov-Smirnov. Después de aceptar, se realizó ANOVA one-way, con post-hoc de Bonferroni a fin de verificar las significancias entre los cuartiles. Se adoptó el nivel de significancia de $p \leq 0.05$. Resultados: No hubo diferencia significativa en la distribución de los atletas entre los cuartiles $(p=0,74)$. Cuando comparamos las otras variables con relación al trimestre de nacimiento de los atletas, tampoco observamos diferencia significativa entre la estatura $(p=0,79)$, alcance de ataque $(p=0,59)$ y bloqueo $(p=0,07)$, yen las puntuaciones de saque, ataque y bloqueo entre los cuartiles. Conclusión: El efecto de la edad relativa no fue observado en los atletas olímpicos de vóleibol, por lo tanto, este fenómeno no está relacionado al desempeño de los atletas. Esto muestra que otras posibles variables pueden influenciar la formación de estos atletas, descartando el fenómeno de la edad relativa. Nivel de evidencia III; Estudio retrospectivo y comparativo.

Descriptores: Distribución por edad; Habilidades; Voleibol.

\section{INTRODUCTION}

As is the case in volleyball, several sports use age categories to group young athletes in order to reduce cognitive, physical and psychological differences, ${ }^{1}$ while mitigating chronological disadvantages and making competitive levels better matched., ${ }^{2,3}$ Although athlete grouping by age appears to be an effective, adequate and incontestable method, individuals grouped in the same age category may have a chronological age difference of up to 12 months, depending on their date of birth. ${ }^{3}$ This chronological age difference in athletes between quartiles of the same age group is known as Relative Age Effect (RAE).,24

The theory explains that this effect occurs due to the biological maturation process that older athletes undergo. ${ }^{2,5}$ Consequently, they would have better anthropometric and performance variables than those born in the second half of the year, ${ }^{6}$ and could therefore influence talent selection in sports.?

The emergence of this phenomenon in sports involves multiple factors. ${ }^{8}$ Literature searches have shown evidence of this effect in various sports, with different levels of performance, and increasing progressively with the level of competence required in the sport. ${ }^{2}$ Moreover, other authors claim that the RAE can also influence an athlete's opportunity to aim at the higher levels. ${ }^{9}$ Therefore, it is of paramount importance to understand the existence of the RAE, which aims to reduce the early loss of talented athletes due to this phenomenon. ${ }^{8}$

In recent decades, there has been an increase in the interest shown by researchers in investigating RAE in various team sports, yet the data have proven inconsistent. This effect has been reported in studies involving sports such as soccer, ${ }^{10}$ basketball, ${ }^{11}$ and ice hockey. ${ }^{12-14}$ However, in other sports such as basketball15 and handball,14 this phenomenon has been absent.

Performance in sports is known to be related to the physical and technical skills of individuals. ${ }^{16}$ In addition to these abilities, volleyball is very demanding in terms of the motor skills of athletes, which involve making short, fast movements that are related to technical performance. ${ }^{17}$ Although volleyball is an Olympic sport and very popular today, few studies involving RAE in volleyball have been found. Previous research studies have found evidence of a strong RAE in volleyball world cup participants, but these results were in young female athletes.' In a recent study by Campos et al., ${ }^{17}$ conducted with male volleyball athletes, the authors showed a higher predominance of individuals born in the first quartile of the year in the under-19, under-21, and under- 23 categories, yet this phenomenon was absent in adult athletes.
However, it is worth emphasizing that this study only analyzed the athletes' birth frequency by quartiles, thus discarding several other performance-related variables, such as height, motor performance and technical elements of the players.

In this context, since the RAE is related to anthropometric and performance characteristics, ${ }^{6}$ it is important to investigate whether this phenomenon is present in this sport and whether it could influence motor/anthropometric variables and technical elements. Accordingly, the purpose of this study was to analyze the distribution of athletes'birth frequency by quartile and whether this phenomenon would influence height, attack and defense range, and the athletes' scores during the Rio 2016 Olympics.

\section{MATERIALS AND METHODS}

The sample consisted of 116 adult athletes ( $26.9 \pm 4.2$ years), all male, who scored in the Rio de Janeiro Olympics in August 2016. As in previous studies, ${ }^{3,18,19}$ our data were also collected through public spreadsheets. Therefore, there was no need for review by the local Institutional Review Board (IRB), as the researchers did not undertake any kind of intervention or experiment with the athletes enrolled in the study.

All data on date of birth, height, attack and defensive range, points scored when attacking, blocking and serving, and total points, were collected from the official website of the supreme International Volleyball authority, the International Volleyball Federation (French acronym FIVB). ${ }^{20}$ The data were then separated and tabulated in Excel spreadsheets, in which the athletes were distributed into four birth date quartiles: the $1^{\text {st }}$ $Q$ corresponds to the months of January, February and March, the $2^{\text {nd }}$ $Q$ to April, May and June, and the $3^{\text {rd }} \mathrm{Q}$ to July, August and September, while the $4^{\text {th }} \mathrm{Q}$ covers October, November and December. Accordingly, each quartile corresponds to a trimester, or quarter, of the year.

\section{Statistical analysis}

For data analysis, we used descriptive statistics to acquire mean, percentages, and standard deviation. The chi-square $\left(x^{2}\right)$ test was used to test the relative age effect in order to compare the expected vs observed distribution in the athletes' birth quartiles., ${ }^{3,19}$ We used the Kolmogorov-Smirnov test to assess normality on all other variables. After this was accepted, one-way ANOVA was used along with the Bonferroni post-hoc test to verify significance between quartiles in all variables. A significance level of $p \leq 0.05$ was adopted and all tests were performed in SPSS version 22. 


\section{RESULTS}

Figure 1 shows all the players $(n=116)$ distributed into quartiles (Q) according to their respective quarter of birth, namely Q1 [ $\mathrm{n}=32$ (27.59\%)], Q2 [ $n=30$ (25.86\%)], Q3 [ $n=30$ (25.86\%)] and Q4 [ $n=24$ $(20.69 \%)]$, among which there was no significant difference $(p=0.74)$.

When analyzing the athletes' height in relation to the quartiles, we found no evidence of a statistically significant difference $(p=0.79)$ in the mean and standard deviation of height between Q1 (199.3 \pm 6.2 ), Q2 (199.4 \pm 6.8), Q3 (198.9 \pm 4.3$)$ and Q4 (197.9 \pm 7 ).

We did not observe any statistical differences for attack and defensive range (Figures 2A and 2B) based on the birth Quartiles either ( $p=0.59$ and $p=0.07$, respectively).

Table 1 contains the means and standard deviations of points scored when attacking, serving and blocking, and the total points of the athletes by quartiles of birth, for which no significant differences were corroborated when we considered $p \leq 0.05$.

\section{DISCUSSION}

The purpose of this study was to verify the relative age effect in Olympic volleyball athletes and whether this phenomenon would influence height, motor performance and technical elements, which are important characteristics that could reflect on the development of Olympic teams of this sport.

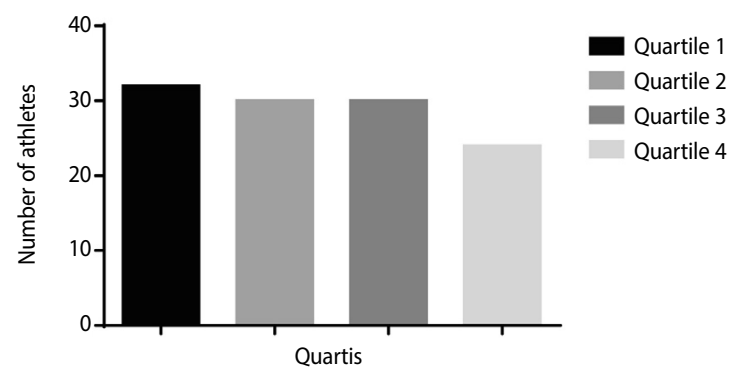

Figure 1. Distribution of birth frequency by quartile of Olympic athletes who scored at the Rio 2016 Olympics $(\mathrm{N}=116)$.
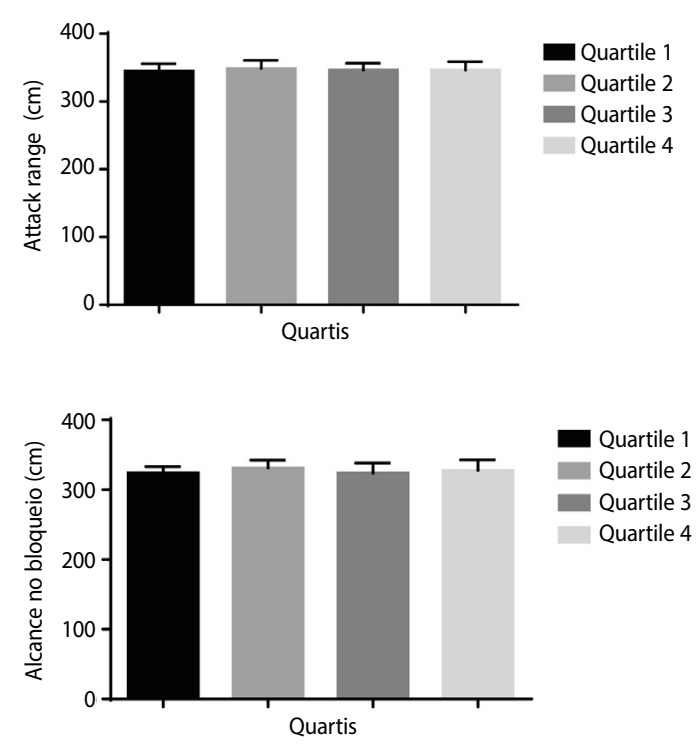

Figure 2. Comparison of the athletes' mean attack and defensive range $(\mathrm{cm})$ by quartile (Figures 2A and 2B, respectively). (No significant difference between ranges by quartiles of birth).
Table 1. Comparison of the attack, block and serve points and total points of the athletes in relation to the quartiles of birth.

\begin{tabular}{c|c|c|c|c}
\hline & $\begin{array}{c}\text { Quartile 1 } \\
\mathbf{M} \pm \mathbf{S D}\end{array}$ & $\begin{array}{c}\text { Quartile 2 } \\
\mathbf{M} \pm \text { SD }\end{array}$ & $\begin{array}{c}\text { Quartile 3 } \\
\mathbf{M} \pm \text { SD }\end{array}$ & $\begin{array}{c}\text { Quartile 4 } \\
\mathbf{M} \pm \text { SD }\end{array}$ \\
\hline Attack points & $35.2 \pm 25.3$ & $26.8 \pm 33.6$ & $30 \pm 28$ & $20 \pm 22.5$ \\
\hline Serve points & $3 \pm 3.1$ & $2.7 \pm 2.9$ & $2.2 \pm 2.3$ & $2.1 \pm 2.9$ \\
\hline Block points & $6.8 \pm 6.5$ & $4 \pm 3.9$ & $4.8 \pm 5$ & $2.8 \pm 2.5$ \\
\hline Total points & $45.2 \pm 30.6$ & $33.6 \pm 38$ & $37.1 \pm 31.7$ & $25.6 \pm 26.4$ \\
\hline
\end{tabular}

The results indicated that RAE was not observed in adult athletes of this sport, i.e., we did not find any difference in the distribution of births of the individuals by quartile. These findings are similar to previous evidence, in which no relative age influence was observed in team sports such as soccer, volleyball, rugby, handball, ${ }^{14}$ and basketball. ${ }^{15}$ Delorme et al. ${ }^{14}$ explain that the absence of RAE in French volleyball is due to the small number of participants in this sport. In addition, other authors claim that in this sport, the RAE progressively decreases as the athletes reach higher levels. ${ }^{17}$ It is worth emphasizing that the sample group of our study represents the world volleyball elite; accordingly, for this level of athlete, it is important to analyze other variables besides RAE.

Regarding the anthropometric variable evaluated, we did not observe significant differences between the mean height of the athletes by quartile. Our findings differ from other team sports such as handball, in which young athletes born in the first quartiles were taller than those born in the second half of the year. ${ }^{21}$ However, unlike the previous study, we used adult athletes ( $26.9 \pm 4.2$ years), which makes this phenomenon less frequent. ${ }^{15,21}$ In addition, the literature shows that the measurement of this anthropometric characteristic is a determining factor to assist coaches in the formation of volleyball teams, ${ }^{22}$ therefore it appears to be a more important variable in forming Olympic teams, thus discarding the RAE.

In the current study, for the variables related to motor performance, it was not possible to observe differences in terms of the average attack and defense range of athletes between quartiles. These two other variables are directly related to vertical jump performance, which is an important element for success in volleyball, ${ }^{23}$ and which in turn is associated with the production of force. ${ }^{24,25}$ Although the phenomenon of relative age is more frequent in sports that demand strength and power from athletes, 2,4,26 our findings indicate that this is not the case in volleyball. In other studies, the idea that technical or motor skills can be a determinant of success is upholded, ${ }^{27}$ once again discarding the RAE in this particular sport.

The athletes'scores during the competition were not influenced by the RAE, a variable that is related to the individuals'technical performance. A recent study of male basketball athletes showed that older players from the under-20s category scored higher and performed better than younger athletes from the same category. ${ }^{11}$ However, in our article, this phenomenon did not influence the score of the athletes of this sport. It is worth noting that the attack, ${ }^{28}$ serve $^{29}$ and block ${ }^{30}$ scores are factors that involve a complex of tactical skills that determine the outcome of high level games. Thus, several factors may explain other possible variables allegedly related to the players'score, ruling out the RAE.

Although we know that the RAE is constantly observed in many team sports, ${ }^{2}$ birthdates cannot be used on their own to select athletes, let alone to form teams, since, as we have seen in volleyball, several other factors will influence success in a sport. Therefore, it is important to make coaches aware of the importance of placing value on athletes' height, motor and technical abilities, and to discard the date of birth when selecting athletes and forming volleyball teams. 


\section{CONCLUSIONS}

We concluded that no relative age effect was observed in Olympic volleyball athletes, and that this phenomenon is not related to anthropometric, motor and technical variables. Understanding this effect is of paramount importance to prevent coaches from excluding their athletes prematurely based on their date of birth. Therefore, our results show that other possible variables could influence the development of athletes who play at an international level, such as strength, jump performance and technical performance, and that these are not subject to any form of influence by the RAE.

\section{ACKNOWLEDGMENTS}

To CAPES and the Universidade Federal do Ceará for their financial support.

All authors declare no potential conflict of interest related to this article

AUTHORS' CONTRIBUTIONS: Each author made significant individual contributions to this manuscript. LFFS and LVSN: data analysis, writing and revision. The authors reviewed and approved the final version of the manuscript.

\section{REFERENCES}

1. Okazaki FH, Keller B, Fontana FE, Gallagher JD. The relative age effect among female Brazilian youth volleyball players. Res Q Exerc Sport. 2011;82(1):135-9.

2. Cobley S, Baker J, Wattie N, Mckenna J. Annual age-grouping and athlete development: A meta-analytical review of relative age effects in sport. Sports Med. 2009;39(3):235-56.

3. Werneck FZ, Lima JR, Coelho EF, Matta MO, Figueiredo AJ. Efeito da idade relativa em atletas olímpicos de Triathlon. Rev Bras Med Esporte. 2014;20(5):394-7.

4. Musch J, Grondin S. Unequal competition as an impediment to personal development: a review of the relative age effect in sport. Developmental Review. 2001;21(2):147-67.

5. Romann M, Cobley S. Relative age effects in athletic sprinting and corrective adjustments as a solution for their removal. PLoS One. 2015;10(4):1-12

6. Gil SM, Badiola A, Bidaurrazaga-Letona I, Zabala-Lili J, Gravina L, Santos-Concejero J, et al. Relationship between the relative age effect and anthropometry, maturity and performance in young soccer players. J Sports Sci. 2014;32(5):479-86

7. Baxter-Jones A, Helms P. Born too late to win? Nature. 1994;370(6486):186.

8. Brazo-Sayavera J, Martínez-Valencia MA, Müller L, Andronikos G, Martindale RJ. Relative age effects in international age group championships: A study of Spanish track and field athletes. PLoS One. 2018;13(4):e0196386.

9. Baker J, Logan AJ. Developmental contexts and sporting success: birth date and birthplace effects in national hockey league draftees 2000-2005. Br J Sports Med. 2007;41(8):515-7.

10. Mujika I, Vaeyens R, Matthys SP, Santisteban J, Goiriena J, Philippaerts R. The relative age effect in professional football club setting. J Sports Sci. 2009;27(11):1153-8.

11. Arrieta H, Torres-Unda J, Gil SM, Irazusta J. Relative age effect and performance in the U16, U18 and U20 European Basketball Championships. J Sports Sc. 2016;34(16):1530-4.

12. Barnsley RH, Thompson AH, Barnsley PE. Hockey success and birthdate: the relative age effect. J Canadian Assoc Health Phys Educ Recreation. 1985;51(8):23-8.

13. Barnsley RH, Thompson AH. Birthdate and success in minor hockey: the key to the NHL. Canad J Behav Sci. 1988;20(2):167-76.

14. Delorme N, Boiché J, Raspaud M. The effect of relative age on elite sport: the French case. Res Q Exerc Sport. 2009;80(2):336-44.

15. Werneck FZ, Coelho EF, Oliveira HZ, Ribeiro Júnior DB, Almas SP, Lima JR, et al. Relative age effect in Olympic basketball athletes. Science Sports. 2016;31(3):158-61.

16. Giannopoulos N, Vagenas G, Noutsos K, Barzouka K, Bergeles N. Somatotype, level of competition, and performance in attack in elite male volleyball. J Hum Kinet. 2017;58:131-40.
17. Campos FA, Stanganelli LC, Rabelo FN, Campos LC, Pellegrinotti IL. The relative age effect in male volleyball Championships. Int J Sports Sci. 2016;6(3):116-20.

18. Penna EM, Moraes LC. Efeito relativo da idade em atletas brasileiros de futsal de alto nível. Motriz. 2010;16(3):658-63

19. Albuquerque MR, Lage GM, da Costa VT, Ferreira RM, Penna EM, Moraes LC, et al. Relative age effect in Olympic taekwondo athletes. Percept Mot Skills. 2012;114(2):461-8.

20. Federação Internacional de Voleibol (FIVB). Rio 2016 [acesso em 2017 nov 17]. Disponível em: http://rio2016.fivb.com/

21. Camacho-Cardenosa A, Camacho-Cardenosa M, González-Custodio A, Martínez-Guardado I, Timón $\mathrm{R}$, Olcina $\mathrm{G}$, et al. Anthropometric and physical performance of youth handball players: the role of the relative age. Sports (Basel). 2018;6(2).pii:E47.

22. Aouadi R, Jlid MC, Khalifa R, Hermassi S, Chelly MS, Van Den Tillaar R, et al. Association of anthropometric qualities with vertical jump performance in elite male volleyball players. J Sports Med Phys Fitness. 2012;52(1):11-7.

23. Sattler T, Hadzic V, Dervisevic E, Markovic G, Vertical jump performance of professional male and female volleyball players: effects of playing position and competition level. J Strength Cond Res. 2015;29(6):1486-93.

24. Sheppard JM, Cronin JB, Gabbett TI, McGuigan MR, Etxebarria N, Newton RU. Relative importance of strength, power, and anthropometric measures to jump performance of elite volleyball players. J Strength Cond Res. 2008;22(3):758-65.

25. Ziv G, Lidor R. Vertical jump in female and male volleyball players: a review of observational and experimental studies. Scand J Med Sci Sports. 2010;20(4):556-67.

26. Raschner $C$, Müller $L$, Hildebrandt $C$. The role of a relative age effect in the first winter Youth Olympic Games in 2012. Br J Sports Med. 2012;46(15):1038-43.

27. van Rossum JH. Relative age effect revisited: findings from the dance domain. Percept Mot Skills 2006;102(2):302-8

28. Zetou E, Tsigilis N, Moustakidis A, Komninakidou A. Playing characteristics of men's Olympic Volleybal teams in complex II. Int J Perf Analysis Sport. 2006;6(1):172-7.

29. Zetou E, Moustakidis A, Tsigilis N, Komninakidou A. Does effectiveness of skill in complex I predict win in men's Olympic volleyball games? Int J Perf Analysis Sport. 2007;3(4):3.

30. Palao JM, Santos JA, Ureña A. Effect of team level on skill performance in volleyball. Int J Perf Analysis Sport. 2004;4(2):50-60 